\title{
ULTRASTRUCTURE OF BLOOD VESSELS IN THE COURSE OF ENDOCHONDRAL OSSIFICATION IN CATTLE
}

\author{
H. ČERNÝ \\ Department of Anatomy, Histology and Embryology, University \\ of Veterinary Science, 61242 Brno
}

Received November 27, 1981

\begin{abstract}
Černý H.: Ultrastructure of Blood Vessels in the Course of Endochondral Ossification in Cattle. Acta vet. Brno, 52, 1983: 15-26.

Blood vessels were studied in cattle in the course of endochondral ossification using the metaphyseal margin of the growth cartilage of the tuber coxae. Four fetuses aged $246-271$ days, 2 adults aged 3 years, and one adult aged 3.5 years were used in the study.

The experimental material was prepared by conventional methods employed for transmission electron microscopy.

From the radially passing blood vessels of the osteoid zone capillaries arose which were directed proximally towards the zone of hypertrophying chondrocytes. These blood vessels resembled sinusoidal blood capillaries. Proximally, they terminated as blind apices, reminiscent of vascular buds. The wall of these capillaries was composed of only the attenuated processes of the endothelial cells; they demonstrated no basement membrane or pericytes.

The wall integrity of blood vessels was often interrupted and the endothelial cells were discontinuous. This resulted in microhaemorrhages with erythrocytes and blood plasma appearing in pericapillar space. In the course of endochondral ossification in the osteoid zone, so-called open vessels have repeatedly been found in our material which seem to be a species trait in cattle. The blood capillaries and free erythrocytes were in direct contact with the ground substance of the cartilaginous model.

Using ultrathin sections, a detailed description is given of the topography of blood capillaries and cartilage in the course of endochondral ossification in cattle osteogenesis.

An original finding presented is the demonstration of blood vessels with impaired endothelium integrity.
\end{abstract}

Cattle, endochondral ossification, blood vessels, ultrastructure.

The relationship between the hypertrophic calcified cartilage and blood vessels was investigated along with the ultrastructure of endochondral ossification in the course of osteogenesis under both natural and experimental conditions.

The role of blood circulation in normal ossification has been described in detail. Much attention has been focused on the differentiation of cellular elements, having their origin from endothelial cells of blood capillaries, cells which play a role in cartilage resorption (Trueta and Little 1960; Larson 1976) or in osteogenic cells (Pritchard 1952).

In the present work, the so-called "open vessels" in the osteoid zone of ossification were investigated. In close vicinity of capillaries free erythrocytes have been detected outside the blood vessels (Trueta and Little 1960; Trueta 1968; Anderson and Parker 1966; Schenk et al. 1967, 1968) forming microhaemorrhage with blood plasma. Free erythrocytes have also been described in the course of epiphyse ossification (Kalayian and Cooper 1972), and in the developing capillaries in areas of secondary ossification centres (Kugler et al. 1979). 


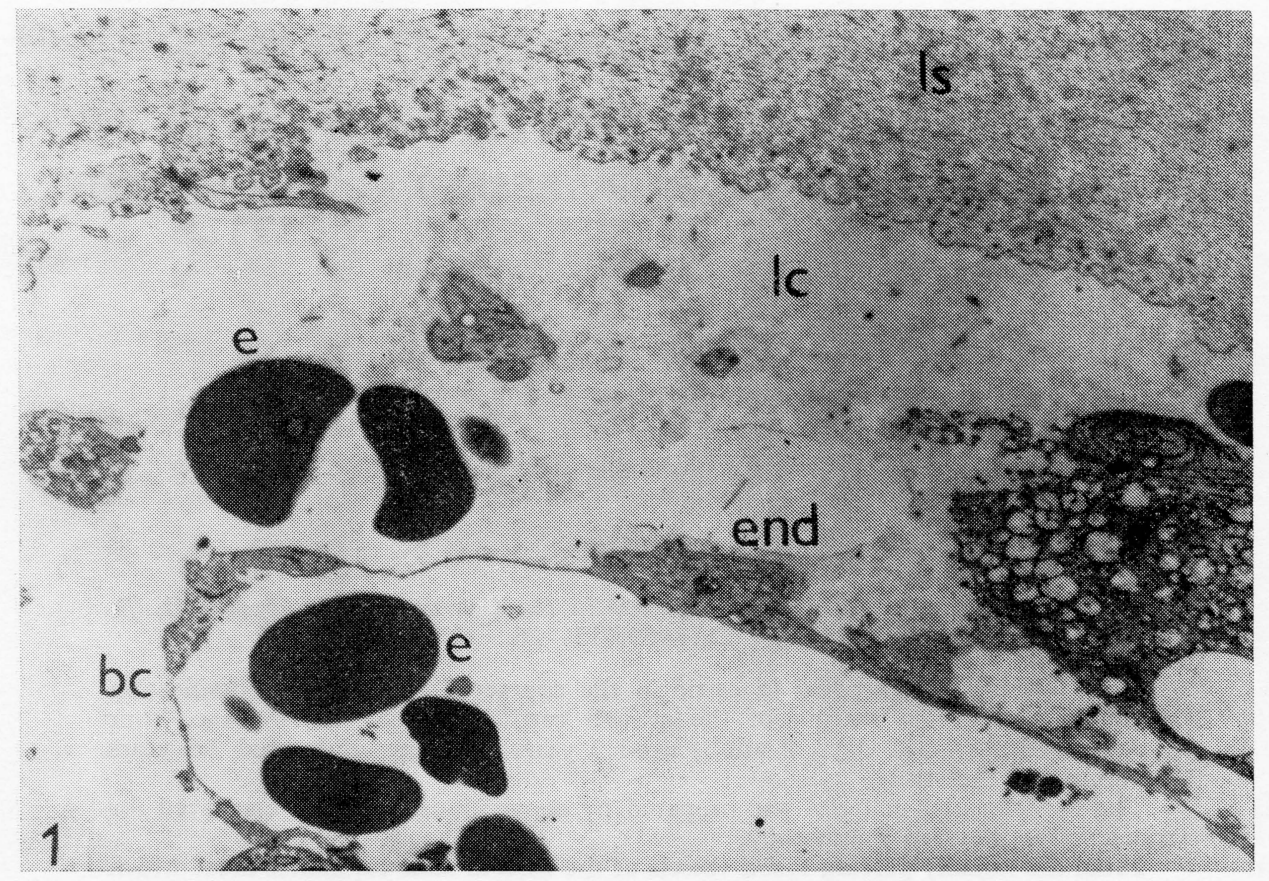

Fig. 1. Penetrating blood capillary in an empty lacuna. Erythrocytes and an accompanying cell interposed between the capillary wall and the longitudinal septum; ls - longitudinal septum, lc - lacuna, e - erythrocyte, end - endothelial cell with processes, bc - blood capillary with a blind bud. $\times 4000$.

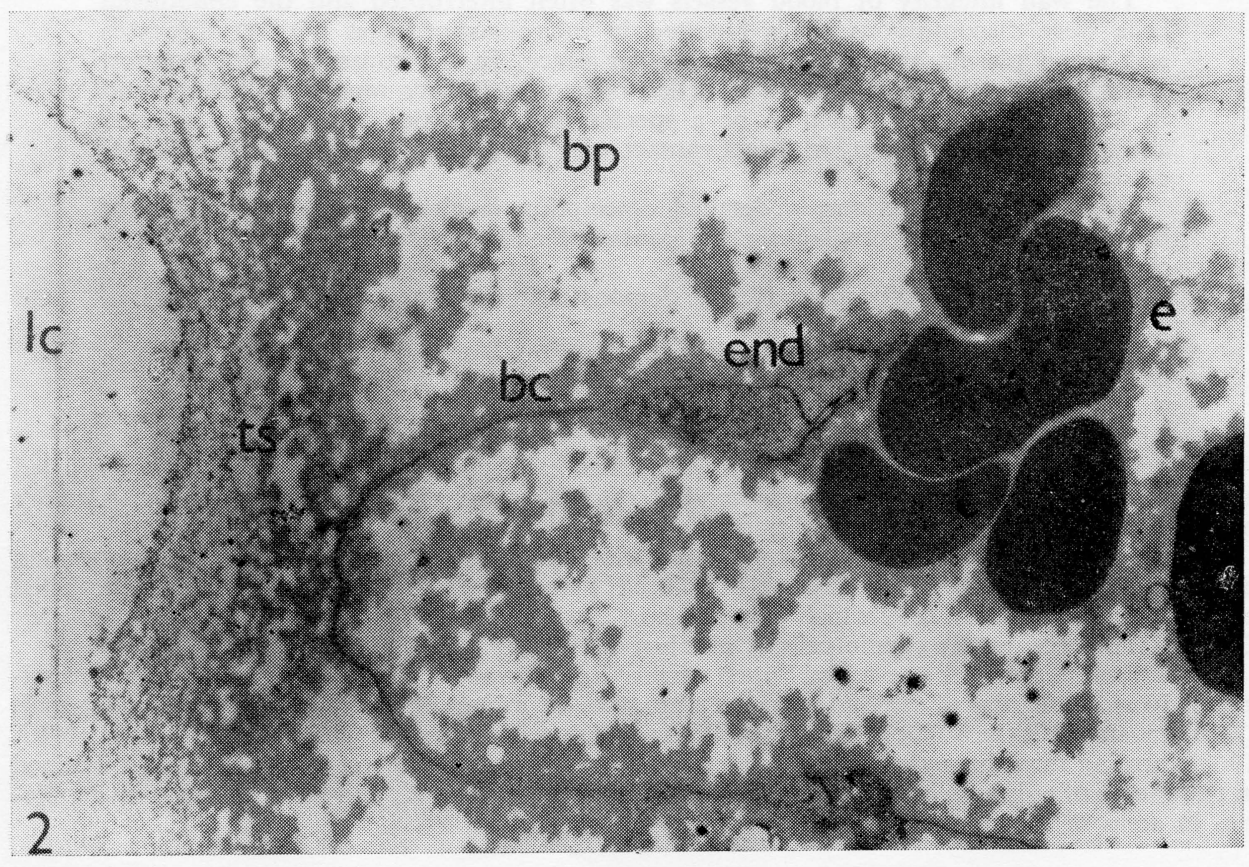




\section{Material and Methods}

Samples were collected from 4 bovine fetuses aged 246 to 271 days, from 2 adults aged 3 years, and one adult aged 3.5 years. The samples were taken from the metaphyseal margin of the growth cartilage of the tuber coxae.

The specimens were fixed with $4 \%$ glutaraldehyde in $0.1 \mathrm{M}$ phosphate buffer at $\mathrm{pH} 7.4$ for $4 \mathrm{~h}$, decalcified in $0.1 \mathrm{M}$ EDTA with $4 \%$ glutaraldehyde at $\mathrm{pH} 7.4$ for $14-16 \mathrm{~h}$, postfixed in $1 \% \mathrm{OsO}_{4}$, and embedded in Durcupan ACM. Ultrathin sections were cut with an ultramicrotome Tesla BS 490, counterstained with uranyl acetate and lead citrate, examined and photographed with a Tesla 613 transmission electron microscope (TEM).

\section{Results}

Blood vessels in the osteoid zone passed from the periosteal surface radially between the trabeculae so that they generally appeared transverse in longitudinally oriented sections. From these vessels capillary buds arose, passing toward the closest lacuna. The TEM revealed in detail the blood vessel invasion. These vessels passed in parallel with the trabeculae of mineralized cartilage toward the last hypertrophied chondrocyte of a chondrocyte column. The capillaries were similar to sinusoidal capillaries. Their lumen was irregular and relatively wide; their wall was composed of only the attenuated thin projections of the endothelial cells. The basement membrane was absent and no pericytes were visible. The capillaries passed proximally towards the cartilage, and they were often accompanied by extravascular erythrocytes. The erythrocytes were interposed between the ground substance of the mineralized cartilage and capillaries. Along with capillaries also numerous cellular elements appeared in the lacunae. These cells arose most probably from the endothelial cells or by differentiation of mesenchymal cells occurring in large numbers in the osteoid zone interposed with capillaries and trabeculae of the mineralized cartilaginous ground substance and they filled the pericapillar spaces. The proximal ends of capillaries formed the vessels buds. These originated from vessels of the osteoid zone piercing the cartilage. In the course of penetration the cartilage, some of the vessels opened near their apices as soon as at the level of the metaphyseal margin of the cartilage where also free erythrocytes passed into the pericapillar space.

The apex of the budding capillary contacted directly the transversal interlacunar septa. In some instances, numerous erythrocytes filled the lacunae and contacted directly the ground substance of the cartilage. Along with erythrocytes also the blood plasma flowed from capillaries into the pericapillar space or into the lacunar space, giving rise to microhaemorrhages filling these spaces.

The hypertrophied chondrocyte pushed toward the longitudinal septum by the capillary tip was in direct contact with the capillary of the accompanying cell.

Around the capillary separated additional cellular elements may be seen along with erythrocytes in several lacunae. With blood plasma they formed the lacunar contents.

Fig. 2. Direct contact of the capillary bud with the transversal septum; lc - lacuna, ts - transversal septum, bc - blood capillary, end - endothelial cell, e - erythrocytes, bp - blood plasma. $\times 7300$. 


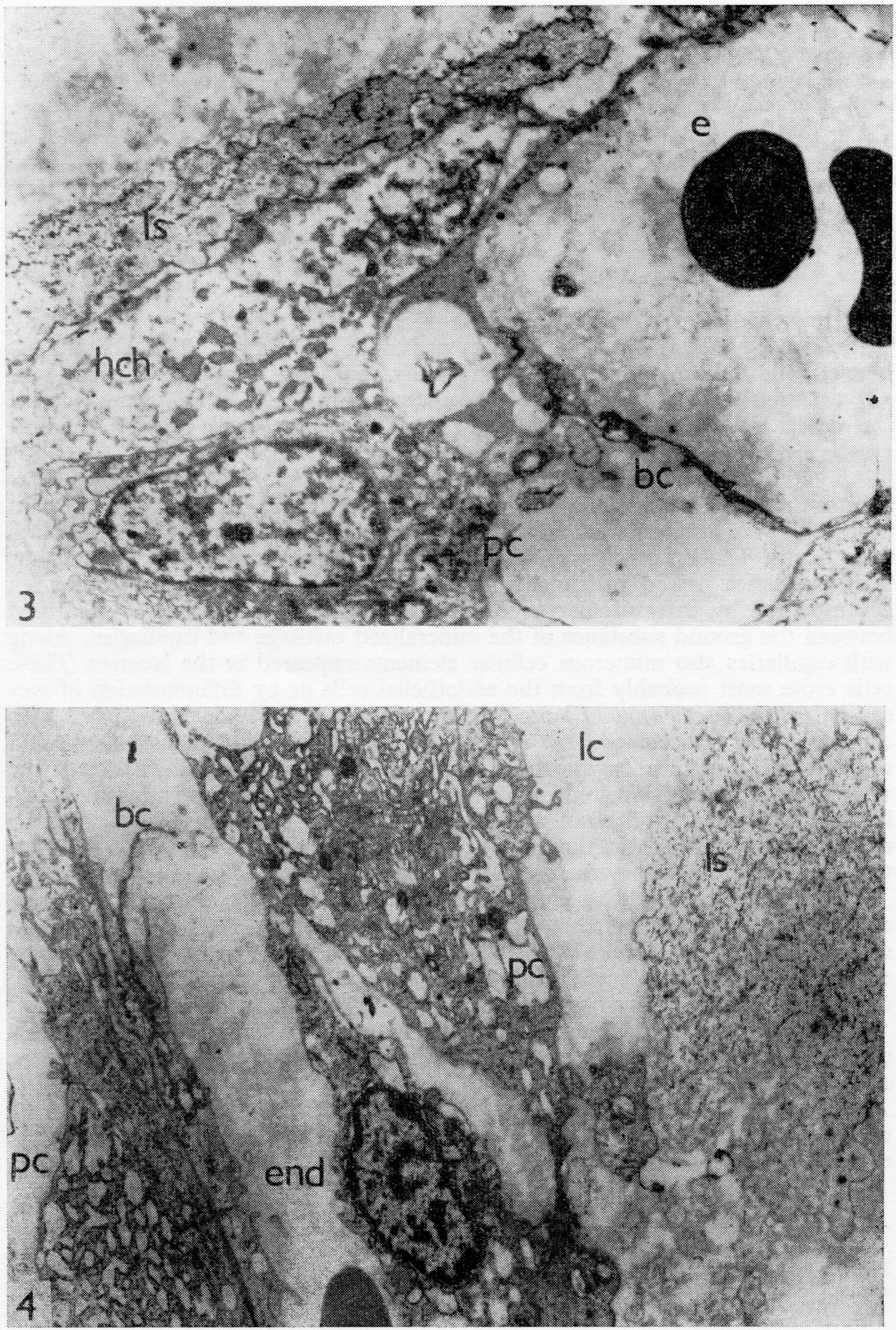


Fig. 3. The tip of a penetrating capillary and an accompanying cell in close contact with disintegrated hypertrophying chondrocyte; ls - longitudinal septum, hch - hypertrophying chondrocyte, bc - tip of the capillary, e - erythrocyte, pc - pericapillar accompanying cell. $\times 7300$.

After the transversal septum lysed, some of the penetrating capillaries opened and invaded the lacunae along with associated cells. In close vicinity of the vessel were small fragments of the ground substance of the cartilage representing the remnants of the septum, and some organelles of the disintegrated chondrocyte. These were mainly vesicular structures of various sizes with contents or subcellular membrane fractions.

Disconnection of the cytoplasmic processes of the endothelial cells cccurred at multiple foci along the wall of the penetrating capillary (see Fig. 6). Erythrocytes and blood plasma entered the lacunar space through wide openings.

The morphological appearance of the relationship between blood capillaries and mineralized hypertrophied cartilage is rather variable. Besides well-preserved lacunae with hypertrophied chondrocytes in various stages of disintegration we found lacunae with destroyed transversal septum. They communicated with the intertrabecular spaces. The lacunar contents consisted of free erythrocytes, blood plasma and numerous pericapillar cells. Some of the lacunae were filled but with blood plasma.

\section{Discussion}

Existence of so-called "open vessels" in the course of endochondral ossification of a cartilaginous model has been demonstrated in several mammalian species including man (Trueta 1968).

In the opinion of Cameron (1961), the endothelial cells of these capillaries are very active in resorption of the mineralized ground substance of the cartilage. This conclusion was based on the observation of penetrating capillaries intimately surrounded by mineralized cartilage. The erosive action of capillary wall upon the mineralized ground substance makes itself felt in penetration through this type of tissue. The author postulated that the principal mechanism of capillary erosion lies in insufficient blood flow (and concurrent decrease in $\mathrm{O}_{2}$ supply) in the growing blind-ended capillary buds, especially at early stages of the process. A possible role of proteolytic enzymes in this process was also suggested (Cameron 1961). In support of this proposed erosive activity of capillaries, we observed that the wall of invading vessels often demonstrates no direct contact with the resorbed matrix, as is the case of cellular resorption.

The damaged wall of capillaries of the sinusoid type results in microhaemorrhages. We support the conclusions of Trueta (1968), i. e. that their existence is of functional importance. According to Trueta (1968), interposition of erythrocytes between the capillary tip and the septum is essential for breaking of the transversal septa. In our material, there also was a direct contact of the endothe-

Fig. 4. Blood capillary with open tip and pericapillar cellular elements; ls - longitudinal septum, lc - lacuna, bc - blood capillary with open tip, end - endothelial cell, pc - pericapillar cells. $\times 7300$. 


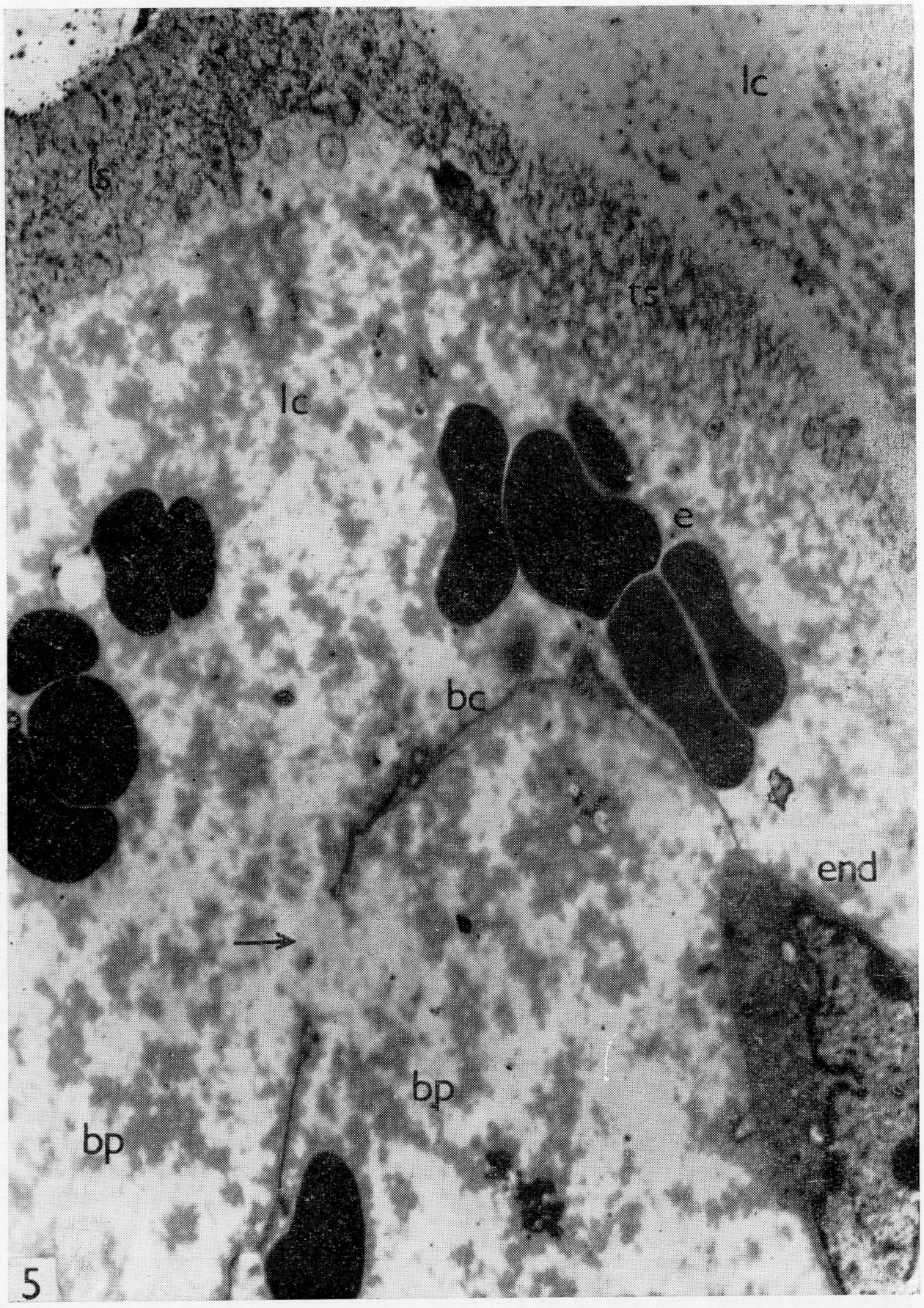

Fig. 5. Detail of a capillary tip; is - longitudinal septum, ts - transversal saptum, lc - lacuna, bc - capillary tip, end - endothelial cell, - e - erythrocytes. bp - blood plasma; impaired endothelium integrity indicated by an arrow. $\times 11800$. 


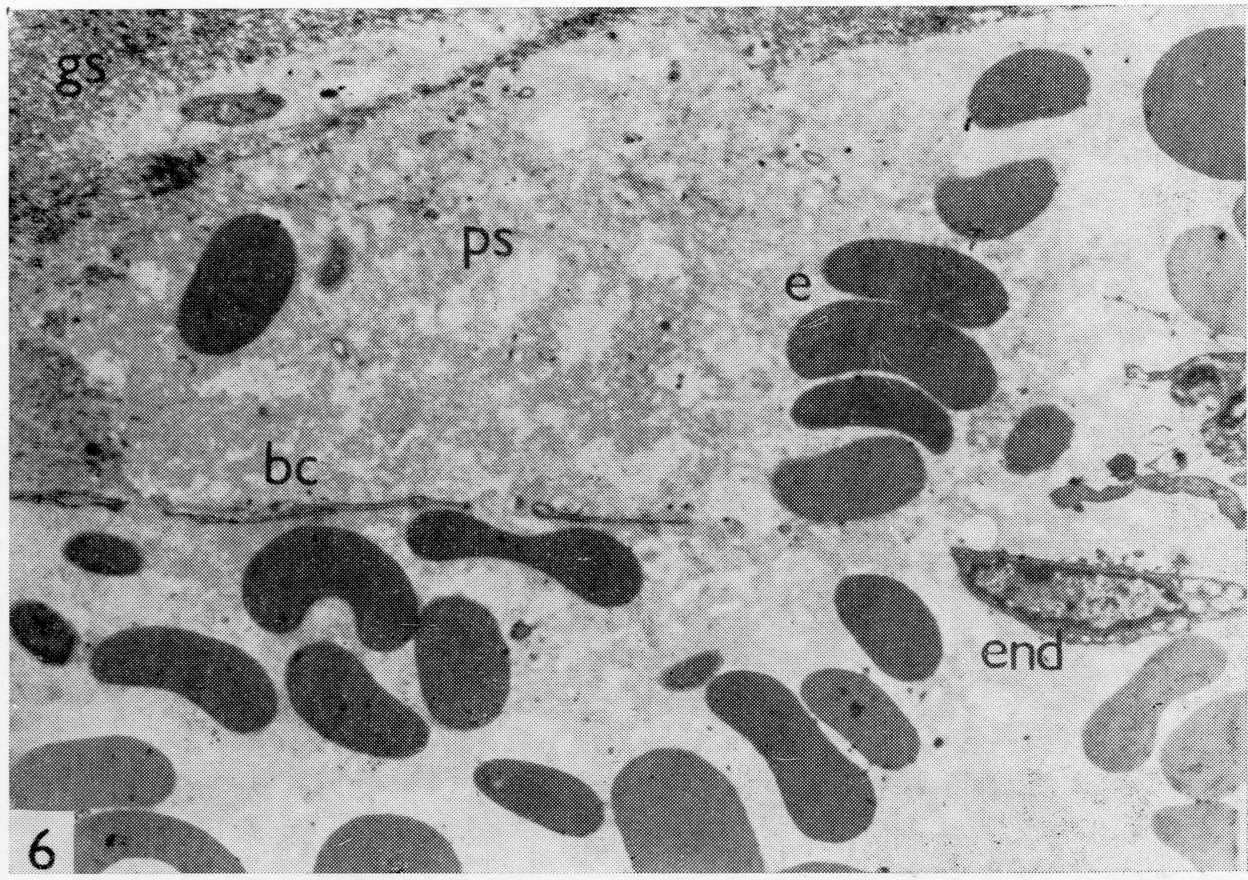

Fig. 6. Impaired capillary wall in the course of ossification; ps - pericapillar space with erythrocytes, end - endothelial cells, bc - blood capillary wall, g3 - ground substance of the cartilage. $\times 4.000$.

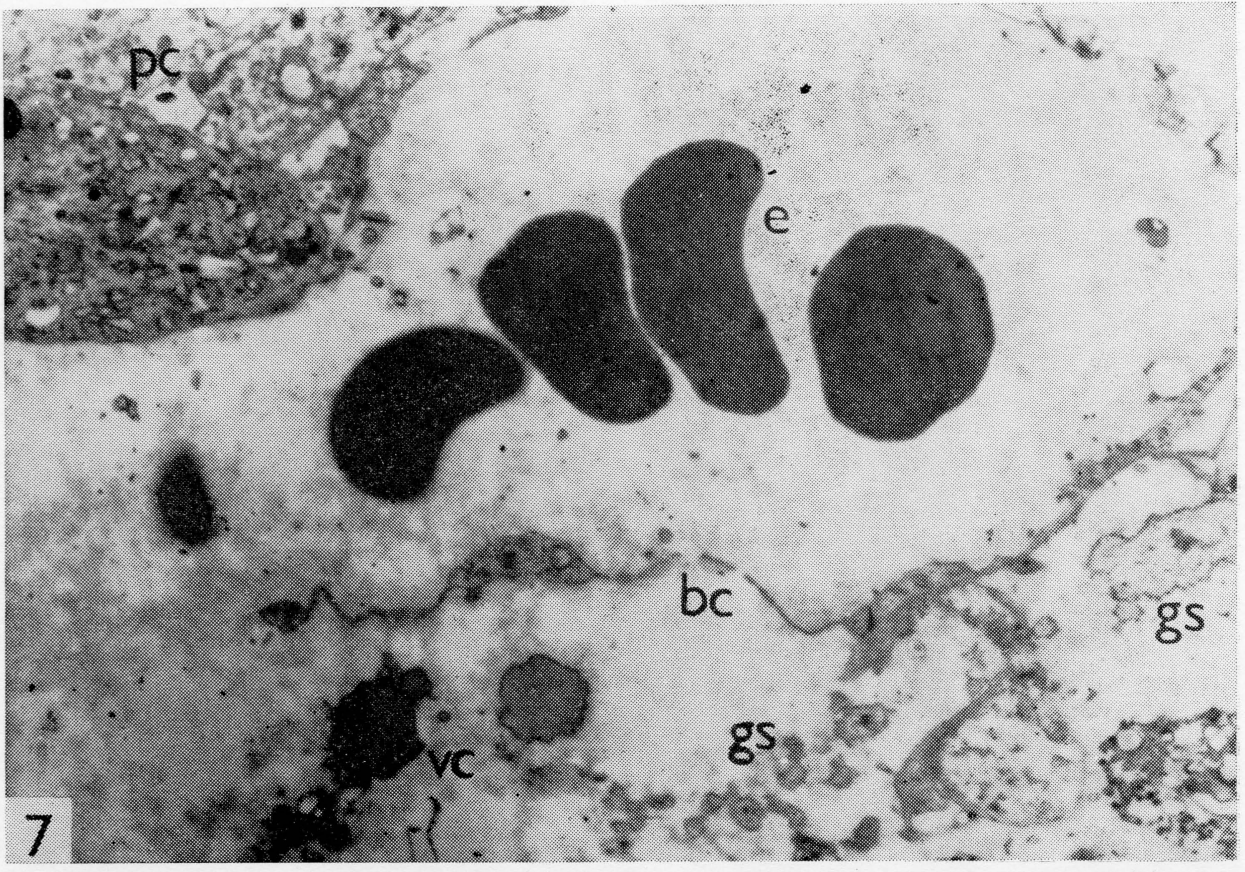

Fig. 7. Widely open capillary bud (tip) at metaphyseal margin of the cartilage; bc - blood capillary, e - erythrocytes, gs - fragments of the ground substance of cartilage, vc - vacuoles with the membrane (subcellular fractions of the disintegrated hypertrophying chondrocyte), pc - pericapillar cells. $\times 7300$. 

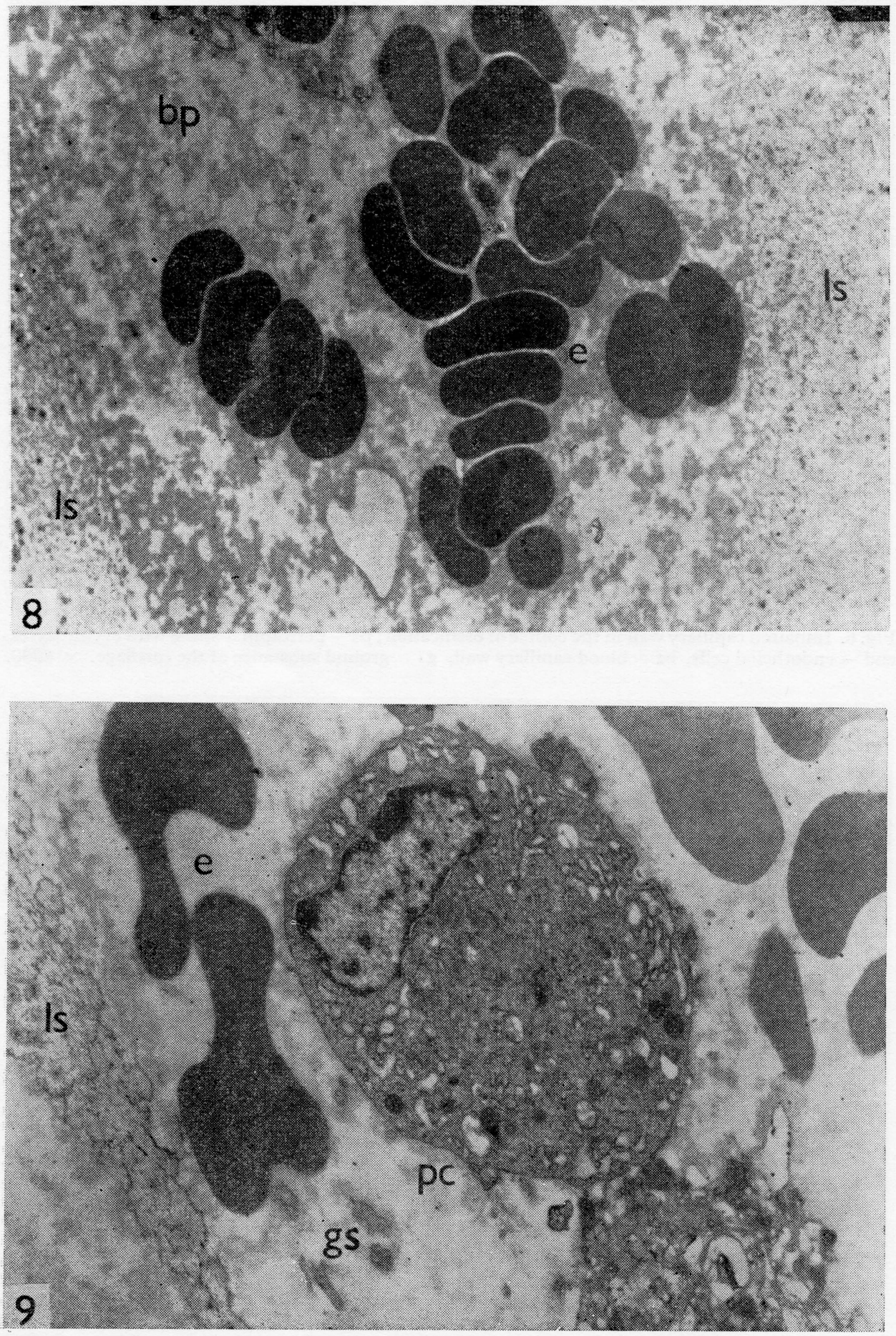
Fig. 8. Free erythrocytes and blood plasma fill the lacuna; ls - longitudinal septum, e - erythrocytes, bp - blood plasma. $\times 4000$.

lial cells with the ground substance of the septum. The endothelial cells exhibit a remarkable resorptive activity and seemingly invade the mineralized ground substance (Lester and Ash 1981).

The microhaemorrhage occurred predominantly at sites of intensive resorption. Along with microhaemorrhages blood capillaries with large openings have been described (Trueta 1968; Schenk et al. 1967, 1968). On the other hand, in the opinion of Kugler et al. (1979), cytoplasmic projections of primitive cells differentiating in endothelial cells penetrate among free erythrocytes and form thus new capillaries. Some of the free erythrocytes are located in the lumen of the developing capillaries, the rest of them remain extravascular.

Zinkernagel et al. (1972) consider the finding of free erythrocytes an artifact occurring in immersion-fixed specimens. This fixation breaks open the capillaries easily. The authors demonstrated intact vessels wall when employing perfusion. This view is also supported by Savostin and Asling (1975).

The blood which is direct contact with both the mineralized matrix and cellular elements may provide a suitable medium for action or transport of active substances attacking or removing breakdown products of the mineralized ground substance of the cartilage. In our opinion, the free erythrocytes present in lacunae or in pericapillar spaces of the osteoid zone exert a chemotactic effect on the clastic cells. Therefore, microhaemorrhages are found predominantly at sites of intensive resorption of the cartilaginous model.

\section{Ultrastruktura krevních cév v enchondrální osifikaci}

Pro studium krevních cév $\mathrm{v}$ enchondrální osifikaci jsme použili metafysární okraj růstové chrupavky kyčelního hrbolu 4 fetů skotu v období 246-271 dní fetálního věku a 3 dospělých jedinců, dvou ve stáŕí 3 let a jednoho ve stáríi 3,5 roku.

Materiál byl zpracován obvyklým způsobem pro potřebu elektronové mikroskopie.

$Z$ radiálně probíhajících krevních cév osteoidní zóny odstupují kapiláry, které směřuji proximálně $\mathrm{k}$ poslednímu hypertrofickému chondrocytu. Tyto krevní kapiláry mají značně široké a nepravidelné lumen a mají charakter sinusoidních krevních kapilár. Proximálně se zakončují slepým vrcholem, takže připomínají cévní pupeny. Jejich stěna je tvořena tenkými výběžky endotelových buněk bez basální membrány a pericytů.

Častým nálezem je porušení celistvosti stěny projevující se rozpojením endotelových buněk. $\mathrm{V}$ souvislosti s tímto nálezem dochází $\mathrm{k}$ mikrohemorhagiím, které se projevuji přitomností erytrocytů i krevní plasmy $\mathrm{v}$ perikapilárním prostoru.

Fig. 9. Free pericapillar cells with erythrocytes in the lacunar cavity; ls - longitudinal septum, gs - fragments of the cartilaginous ground substance, e - erythrocytes, pc - pericapillar cellular elements. $\times 7300$. 


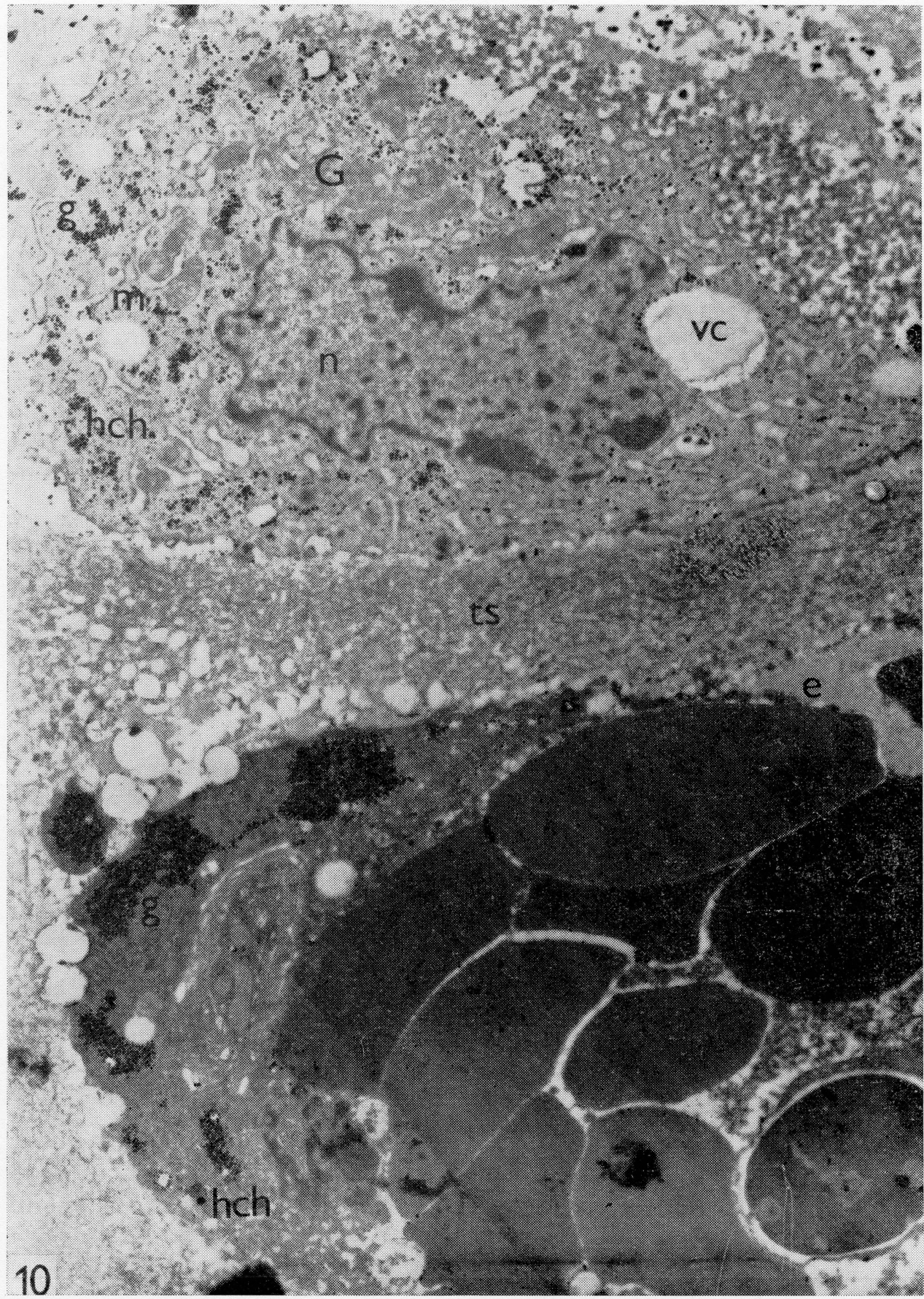

Fig. 10. A hypertrophying chondrocyte and blood cellular elements in a primary marrow cavity after opening the transversal septum; ts - transversal septum, hch - hypertrophying chondrocyte, $\mathrm{n}$ - nucleus, vc - vacuole, $\mathrm{G}$ - Golgi complex, $\mathrm{m}$ - mitochondria, $\mathrm{g}$ - glycogen, $\mathrm{e}$ - erythrocytes. $\times 9800$. 
Zjistili jsme, že u skotu, jako druhu, prokazujeme $\mathrm{v}$ průběhu enchondrální osifikace $\mathrm{v}$ osteoidní zóně tzv. otevřené cévy. Krevní kapiláry spolu s volnými erytrocyty se dostávají do př́mého kontaktu se základní hmotou chrupavčitého modelu. Na ultratenkých řezech jsme podrobně popsali topografické vztahy krevních kapilár a chrupavky $\mathrm{v}$ enchondrální osifikaci $\mathrm{v}$ průběhu ontogeneze.

Za prioritní nález považujeme průkaz existence krevních cév s porušenou endotelovou výstelkou.

\section{Ультраструктура кровеносных сосудов в энхондральной оссификации}

В ходе исследования кровеносных сосудов в энхондральной оссификации нами были использованы метафизарные края ростового хряща бугра таз:бедренного сустава 4 плодов крупного рогатого скота в эмбриональном возрасте 246-271 суток и 3 взрослых животных в возрасте до 3,5 года.

Материал обрабатывался обычным способом для потребностей әлектронной микроскопии.

Из радиально выступающих кровеносных сосудов остеоидной зоны выходят капилляры, направленные проксимально к последнему гипертрофическому хондроциту. Данные кровеносные капилляры отличаются значительно широким иросветом неправильной формы и приобретают характер синусоидальных кровеносных капилляр. Проксимально они завершены слепым бугром, следовательно, они напоминают сосудистые папули. Их стенка состоит из тонких выступов эндотелиальных клеток без базальной мембраны и перицитов.

Часто устанавливают нарушение цельности әндотелия, миграцию эритроцитов и утечку плазмы в перикапиллярное пространство. Нами было выявлено, что у крупного рогатого скота в качестве вида встречаются так называемые открытые сосуды в остеоидной зоне в ходе энхондральной оссификации. Кровеносные капилляры совместно со свободными эритроцитами попадают в непосредственное соприкосновение с основной массой хрящевой модели и мы высказали точку зрения по поводу роли упомянутых кровеносных капилляр и экстраваскулярно ориентированных әритроцитов в процессе резорбции основной массы хряща. На сверхтонких срезах нами были подробно описаны топографические отношения кровеносных капилляр и хряща в ходе энхондральной оссификации в онтогенезе.

Подлинным открытием считаем доказательство существования кровеносных сосудов с нарушенной цельностью эндотелия.

\section{References}

ANDERSON, C. E. - PARKER, J.: Invasion and resorption in enchondral ossification. J. Bone Jt. Surg., 48 A, 1966, 899-913.

BROOKES, M. - LANDON, D. N.: The juxta-epiphyseal vessels in the long bones of foetal rats. J. Bone Jt. Surg., 46 B, 1964, 336-345.

CAMERON, D. A.: Erosion of the epiphysis of the rat tibia by capillaries. J. Bone Jt. Surg., $43 \mathrm{~B}, 1961,590-594$.

KALAYJIAN, D. B. - COOPER, R. R.: Osteogenesis of the epiphysis. Clin. Orthop., 85, 1972, $242-256$.

KNESE, K. H.: Osteoklasten, Chondroklasten. Mineraloklasten, Kollagenoklasten. Acta anat., 83, 1972, 275-288. 
KUGLER, J. H. - TOMLINSON, A. - WAGSTAFF, A. - WARD, S. M.: The role of cartilage canals in the formation of secondary centres of ossification. J. Anat., 129, 1979, 493-506.

LARSON, A.: Light microscopic and ultrastructural observations of the calcifying zone of the mandibular condyle in the rat. Anat. Rec., 185, 1976, 171- 185.

LESTER, K. S. - ASH, M. M.: Ossification in Adult Rat Mandibular Condyle - SEM of Chondroclasia. Journal of Ultrastructure Research, 74, 1981, 46-58.

PRITCHARD, J. J.: A cytological and histochemical study of bone and cartilage formation in the rat. J. Anat. (Lond.), 86, 1952, 259-277.

SAVOSTIN - ASLING, I. - ASLING, C. W.: Transmission and scanning electron microscope studies of calcified cartilage resorption. Anat. Rec., 183, 1975, 373-391.

SCHENK, R. K. - SPIRO, D. - WIENER, J.: Cartilage resorption in the tibial epiphyseal plate of growing rats. J. Cell Biol., 34, 1967, 275-291.

SCHENK, R. K. - WIENER, J. - SPIRO, D.: Fine structural aspects of vascular invasion of the tibial epiphyseal plate of growing rats. Acta Anat., 69, 1968, 1-17.

TRUETA, J. - LITTLE, K.: The Vascular Contribution to Osteogenesis. II. Studies with the Electron Microscope. Bone Jt. Surg. 42 B, 1960, 367-376.

TRUETA, J. - MORGAN, J. D.: The vascular contribution to osteogenesis. I. Studies by the injection method. J. Bone Jt. Surg., 42 B, 1960, 97-109.

TRUETA, J.: The role of the vessels in osteogenesis. J. Bone Jt. Surg., 45 B, 1963, 402-418.

TRUETA, J.: Studies of the Development and Decay of the Human Frame. W. Heinemann, $1968,389$.

ZINKERNAGEL, R. - RIEDE, U. N. - SCHENK, R. K.: Ultrastrukturelle Untersuchungen der juxta-epiphysären Kapillaren nach Perfusionsfixation. Experientia, 28, 1972, 1205-1206. 